Emir. J. Agric. Sci. (1991). 3: 81-95

\title{
The effect of three fungi and their combinations on the chemical constituents of two cultivars of date palm fruits.
}

Khaled Saad Abdulsalam* Ahmed El Tayeb Mussa* and Ahmed Abdulmohsin**

* King Faisal University, College of Agricultural and Food Sciences, Department of Plant Protection. Hof uf, Saudi Arabia.

** Al-Hassa Irrigation and Drainage Authority. Al-Hassa, Saudi Arabia.

\section{ABSTRACT :}

Three fungi of Alternaria alternata. Aspergillus japonicus and Nigrospora sp. and their combinations were found to be pathogenic on two date palm fruit cultivars; Khisab and Shahl. These fungi also affected the chemical constitutents of fruits from these two cultivars causing significant reduction in total. reducing and non-reducing sugars, protein, moisture and altering their $\mathrm{pH}$ from 7 to 3 .

Four different designed media of date palm fruit agar (DPFA), date palm leaf agar (DPLA), date palm leaf and fruit agar (DPLFA) and date palm leaf and sugar agar (DPLSA) were tested for the growth of the above mentioned fungi. DPLFA was found the best media to enhance the growth of these fungi.

Key words : Chemical constituent, Date palm, Fungi, Sugar agar.

\section{INTRODUCTION}

Date palm (Phoenix dactylifera L.) is known for producing edible dates in hot arid conditions. The date palm 
tree is a good source of food for desert dwellers as well as country farmers and civilized town inhabitants and have been grown as a staple food for thousands of years in the in several places of the world. Chemical changes that occur during the development of dates are important and useful. Except of the few studies reported by Hussein and El-Zeid (1975), Hussein et al. (1975), Hussein et al. (1976), and Sawaya et al. (1982), most of the date palm cultivars grown in Saudi Arabia have not been studied for their compositional changes during fruit maturity especially after attach by different pathogenic organisms which results in severe losses. Djerbi (1981) stated that preharvest date fruit rots are a major problem, governed by climatic conditions particularly by high humidity and rain. Chohan (1972) stated that fungi invade ripening fruits through wounds, especially during periods of rain and high humidity when fruits may split and crack providing easy entery for fungi. Alarosi et al. (1982), reported that genera of Alternaria, Aspergillus, Aureobasidium, Botryodiplodia, Cladosporium, Fusarium, Nigrospilomyces and Penicillium were frequently isolated from Qatif and Al-Hassa plantations in the Eastern Region of Saudi Arabia. Abdulsalam and Mussa (1988) reported five different fungal isolates from date palm fruits at the Khalal stage.

The present study was undertaken to investigate the effect of three different fungi and their combination on the degree of rot caused to two date palm fruit cultivars of Khisab and Shahl at the Khalal stage. The chemical constitutents of the infected cultivars and the growth of these three different fungi on four designed media were also discussed.

\section{MATERIALS AND METHODS}

All experiments were carried out in the Department of 
Plant Perotection laboratory in the College of Agricultural and Food Sciences, King Faisal University, Al-Hassa, Eastern Region of Saudi Arabia. The experiments were carried out on two cultivars of date palm fruits of Khisab and Shahl brought directly from near by plantation at Al-Hassa.

\section{Pathogenicity tests.}

Three different fungi previously isolated by Abdulsalam and Musa 1988. Alternaria alternata, Aspergillus japonicus and Nigrospora sp. and their combinations were tested for their virulence on date palm fruits. The test was carried out on apparently healthy fruits of Khisab and Shahl cultivars at the Khalal stage. These fruits were washed, surface sterilized with $1 \%$ sodium hypochlorite for three minutes then washed with sterilized water and dried with sterilized filter papers, then seperated each with its calyx. Wounding was carried out by piercing fruits with a sterile pointed needle to a depth of $2 \mathrm{~mm}$. Each fruit received one wound near the calyx. Fruits were then inoculated by placing a drop of fungal suspension at the wound. Fruits used as control were treated as before but without receiving inocula. The combination of the fungi were prepared by mixing equal volume of each fungal suspension. Each treatment consisted of ten fruits placed in two polyethelene bags, five per bag. The fruits were then atomised with sterile water and stored at room temperature ranging from $20+2 \mathrm{C}$ for one week. Severity of infection was estimated by measuring fruit rot symptoms according to the following scale :

1. No infection

2. Infection upto $1 / 4$ th of the fruit

3. Infection from $1 / 4$ th upto $1 / 2$ of the fruit

4. Infection from $1 / 2$ upto $3 / 4$ th of the fruit

5. Infection more than $3 / 4$ th of the fruit 


\section{Chemical composition.}

Chemical analyses of date fruits, were carried out for the study of the effect of fungal infection on the chemical constituents of total, reducing and non-reducing sugars, and their effect on protein, moisture, ash and $\mathrm{pH}$ values of the fruit sap.

The infected date fruits were frozen at the end of the experiment, and kept till time of analyses. For analyses fruits were thawn at room temperature, freed from seeds and calyxes. Ten grams from each treatment were then boiled in $150 \mathrm{ml}$ distilled water for $20 \mathrm{~min}$. to which $2 \mathrm{gm} \mathrm{CaCO} 3$ was added to prevent oxidation. The extracts were filtered of through filter paper No.1. The precipitate was extracted again by the same method using $100 \mathrm{ml}$ distilled water then repeated once more. Finally the precipitate was washed by about 100 $\mathrm{ml}$ of distilled water All the filterates of one sample were added together in $500 \mathrm{ml}$ volumetric flask. Lead acetate was added precipitate protein. Excess of lead was removed by the addition of calcium oxalate, then filtered, and the filterate was completed to $500 \mathrm{ml}$ by distilled water (Strong, 1980).

Lane and Eynon's volumetric process (Pearson, 1973), was used for determination of sugars and moisture content. For the determination of protein, ash and $\mathrm{pH}, \mathrm{AOAC}$ (1970) was consulted. Three replicates were carried out for each treatment.

Testing the fungal growth in media three fungi were used in this experiment namely, Alternaria alternata, A. japonicus, and Nigrospora sp. Five media were tried in this study to test their effect on the growth of the above mentioned fungi as follows: Potato Dextrose Agar (PDA), Date Palm Fruit Agar (DPFA), Date Palm Leaf Agar (DPLA), Date Palm Leaf and 
Fruit Agar (DPLA) and Date Palm Leaf and Sugar Agar (DPLSA).

Fungal plugs $3 \mathrm{~mm}$ diameter, were taken from the eriphery hyphal tips of sporulating colonies of each of the five fungi. The plugs were placed on the centre of the petri dish plates containing $15 \mathrm{ml}$ of the five mentioned media after solidification.

Each treatment was replicated five times and incubated at $22+2 \mathrm{C}$ in the laboratory. The linear growth was observed daily and recorded in $\mathrm{cm}$ after 7 days of inoculation.

The media used in the experiments were :

1. DPFA was designed as follows :

$200 \mathrm{gm}$ taken from clean date palm fruits freed from seeds and calyxes extracted for one hour in $700 \mathrm{ml}$ water. 20 $\mathrm{gm}$ of Agar was added to the extract, heated to dissolve then completed by distilled water to $1000 \mathrm{ml}$ then sterilized.

2. DPLFA was designed as follows:

$100 \mathrm{gm}$ taken from clean date palm fruits as above then mixed with $100 \mathrm{gm}$ pinnae taken from the terminal half part of the leaf, and extracted for one hour in $700 \mathrm{ml}$ distilled water then $20 \mathrm{gm}$ of agar was added to the extract, heated to dissolve then completed by distilled water to $1000 \mathrm{ml}$, then sterilized.

3. DPLSA was designed as follows:

$200 \mathrm{gm}$ of pinnae taken from the terminal half part of the leaf and $20 \mathrm{gm}$ of sucrose was added to tht and extracted for one hour in $700 \mathrm{ml}$ distilled water. $20 \mathrm{gm}$ of agar was 
added to the extract, heated to dissolve then completed by distilled water to $1000 \mathrm{ml}$, then sterilized.

For statistical analysis, the least significant differences (LSD) at 0.05 was estimated after testing the null hypothesis and finding the $\mathrm{F}$ value through all these experiments.

4. DPLA designed by Alarosi, 1983

5. PDA difco ready made media.

\section{RESULTS}

\section{Pathogenicity test:}

Table 1 represents the data on the effect of the three fungi and their combination on Khisab and Shahl date palm fruit cultivars. Each of these three fungi significantly increased the disease on the two date palm fruit cultivars causing a higher degree of rot. A. alternata when combined with either A. japonicus or Nigrospora were very severe and caused the highest degree of rot in both cultivars. On the other hand, A. japonicus combined with Nigrospora sp. or A. alternata combined with A. japonicus plus Nigrospora sp. significantly increased the degree of rot for both cultivars compared to the control $(P=0.05)$, but these were the least effective fungi in causing degree of rot for Khisab cultivar in contrast to shahl which revealed a higher degree of fruit rot.

\section{Chemical Composition :}

Table 2 represents the effect of the three species of fungi and their combination on the amount of sugar contents on Khisab and Shahl cultivars. All these fungi significantly affected the total and reducing sugars of both cultivars at $P=$ 
Table 1. Ef fect of three species of fungi and their combination on two date cultivars, Khisab and Shahl measured on scale $1-5$ ( $1=$ No disease, 5 complete rot).

\begin{tabular}{|c|c|c|}
\hline \multirow[t]{2}{*}{ Treatments } & \multicolumn{2}{|c|}{ Degree of rot } \\
\hline & Khisab & Shahl \\
\hline Alternaria alternata & $4.1 \mathrm{~d}$ & $4.7 \mathrm{efg}$ \\
\hline$\underline{\text { Aspergillus japonicus }}$ & $4.4 \mathrm{def}$ & $4.9 \mathrm{~g}$ \\
\hline$\underline{\text { Nigrospora sp. }}$ & $3.5 \mathrm{c}$ & $4.3 \mathrm{de}$ \\
\hline$\underline{\text { A. alt. }}+\underline{\text { A. jap }}$ & $4.6 \mathrm{ef} g$ & $5.0 \mathrm{~g}$ \\
\hline A. alt. $+\underline{\mathrm{Nigr}}$. & $4.7 \mathrm{efg}$ & $4.7 \mathrm{efg}$ \\
\hline A. jap. + Nigr. & $1.8 \mathrm{~b}$ & $4.8 \mathrm{fg}$ \\
\hline$\underline{\text { A. alt. }}+\underline{\text { A. jap. }}+\underline{\text { Nig. }}$ & $1.7 \mathrm{~b}$ & $5.0 \mathrm{~g}$ \\
\hline Check (Non-inoculated) & $1.0 \mathrm{a}$ & $1.0 \mathrm{a}$ \\
\hline
\end{tabular}

SD $P=0.05$

0.42

Figures within a column followed by the same letter are not significantly different. 


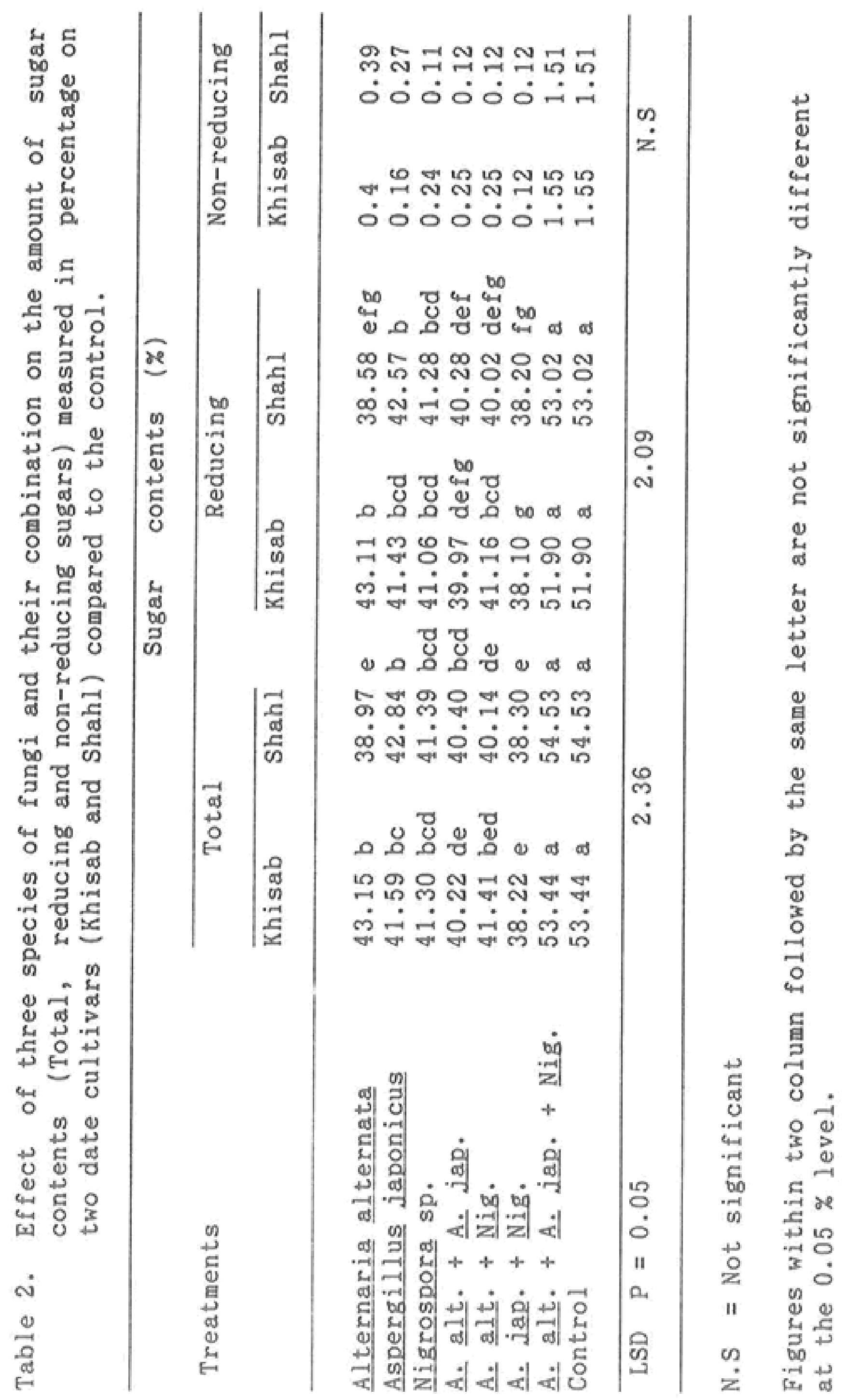


0.05 but they proved non-significant for non-reducing sugar for all treatments. Although the effect of each of these fungi was significantly different in comparison with the control, the combination between any two of these fungi caused a severe loss in percentage total and reducing sugars contents in both cultivars. In spite of the fact that A. alternata caused the highest reduction in percentage of total and reducing sugar contents for Shahl cultivar, the combination of A. japonicus plus Nigrospora sp. caused the highest loss in both cultivars. The combination of the three fungi A. alternata, A. japonicus and Nigrospora sp. caused no significant differences in the percentage of total and reducing sugar contents for Shahl and Khisab cultivars compared to the control.

Table 3 represents the effect of the three fungi and their combination on the amount of protein, moisture, ash and $\mathrm{pH}$ value on the two date fruit cultivars. These three fungi and their combination significantly reduced the percentage of protein, moisture and ash, and also caused significant drop in $\mathrm{pH}$ value in both cultivars. The combination of A. alternata with either A. japonicus or Nigrospora sp. showed the highest reduction in the percentage of protein and moisture contents for both cultivars. The fungi A. alternata and Nigrospora sp. caused higher reduction in the percentage of protein in Shahl cultivar than in Khisab cultivar. However, the combination of A. japonicus plus Nigrospora sp. caused the same level of damage in the percentage of protein for both cultivars. On the other hand, the combination of the $t$ significantly reduced the percentage of protein level in Khisab cultivar than in Shahl cultivar. The moisture percentage was highly reduced by the combination of A. japonicus and Nigrospora sp. in Khisab cultivar than in Shahl cultivar. The three fungi combined together, severely reduced the percentage of moisture of Khisab more than Shahl. However, it is quiet clear from this data that the percentage of the moisture content was 


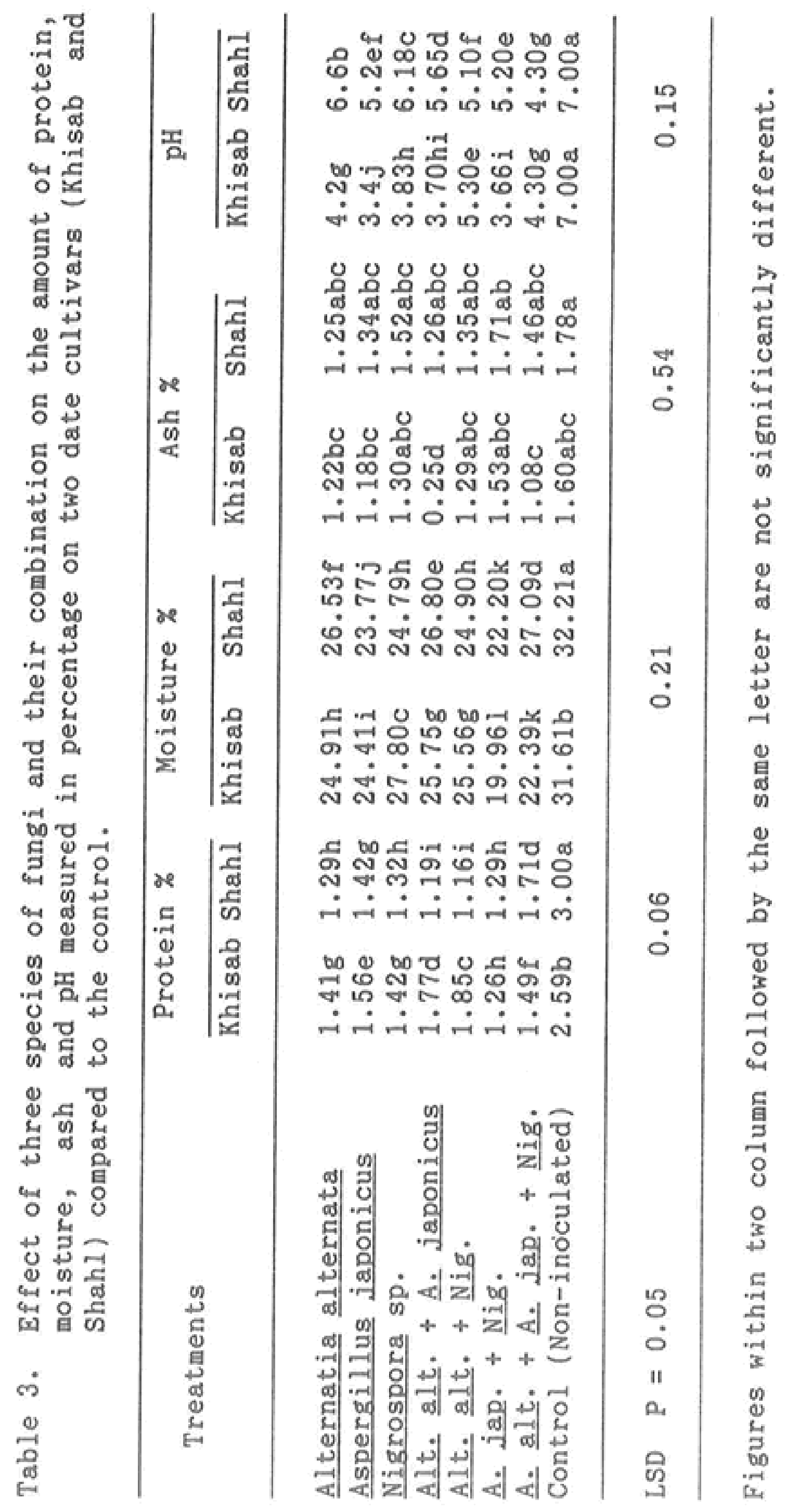


significantly reduced when the three fungi and their combination attached these date palm fruits. Also these results showed that there were no significant differences among those fungi and their combionations. Results of the pHvalues indicated that A. japonicus caused the highest drop in $\mathrm{pH}$ level in Khisab cultivar only. However, all the pathogenic fungi and their combination significantly reduced $\mathrm{pH}$ values in all treatments compare to the control. The fungus A. japonicus plus Nigrospora sp. also decreased the $\mathrm{pH}$ level in Khisab more than Shahl cultivar. A. alternata combined with A. japonicus gave the same degree of reduction in $\mathrm{pH}$ level for Khisab culivar but proved non-significant in comparison with Shahl. However, the data presented in table showed some variations in the level of $\mathrm{pH}$ for both cultivars.

The effect of the media on the fungal growth :

Table 4 represents the effect of five different media on the growth of the three mentioned fungi. This Table shows that DPFA and DPLFA enhanced the growth of all fungi. On the other hand, the designed medium DPLA enhanced the growth of A. japonicus. DPLSA reduced the growth of Nigrospora sp.

\section{DISCUSSION}

Date palm fruits, similar to other fruits are attached by diseases causing a great damage to their quality. The result of this study showed that the combined inoculations of $\mathrm{A}$. alternata plus A. japonicus or A. alternata plus Nigrospora sp. in all tested cases were very pathogenic and they significantly increased the rate of rot in date palm fruits more than if each of these fungi was inoculated alone. These findings are in harmony with the work reported by Elarosi (1983). It iwas noticed that all these fungi and their combination were 
Table 4. Effect of the five different media on the growth of three fungi, seven days af ter inoculation.

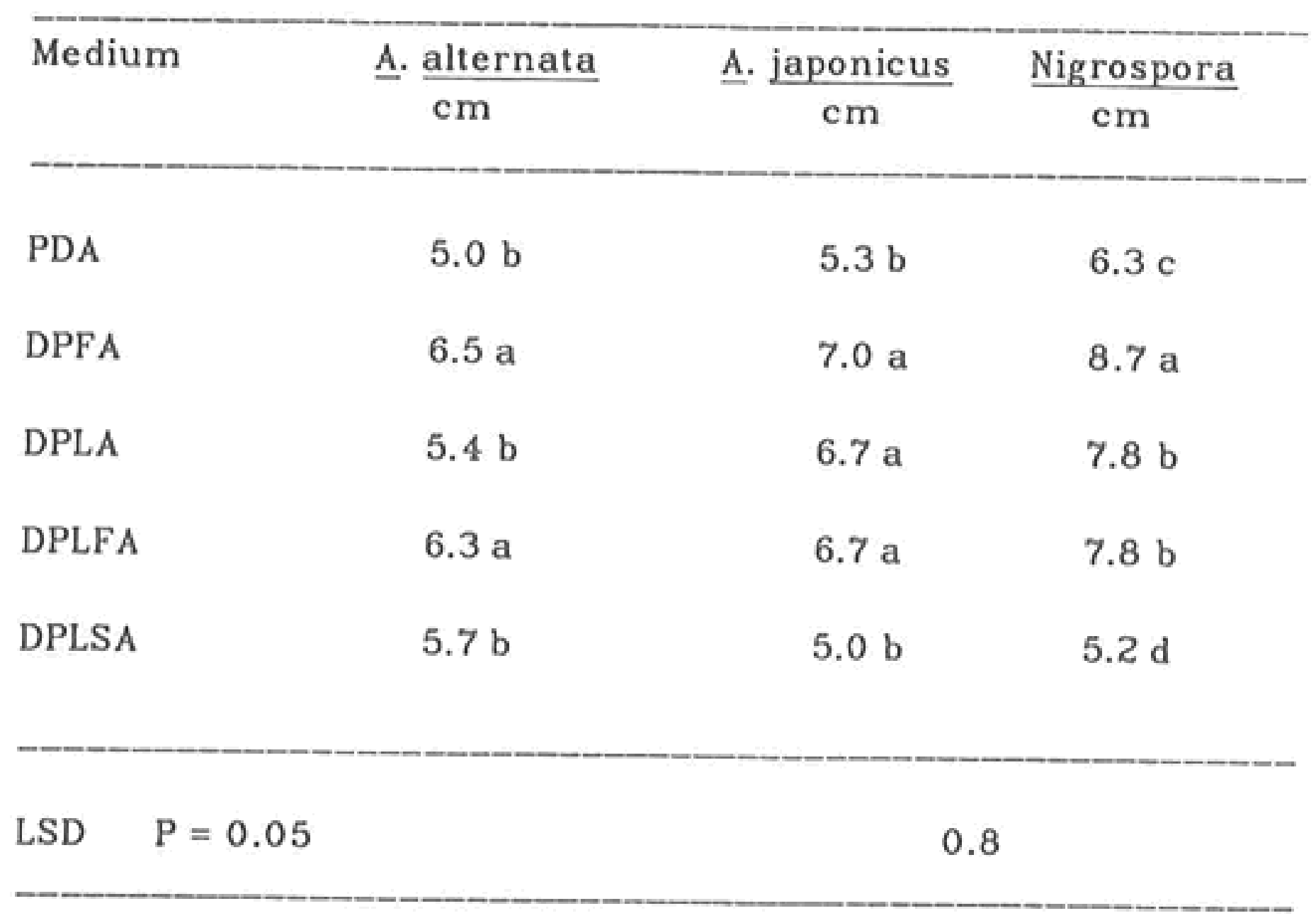

Figures within a column followed by the same letter are not significantly different. 
affecting the chemical constituents of the date palm fruits causing severe damage to their flesh. The gereduction in sugars resulted from normal respiration of fruit tissues and of mycelial growth of inoculated fungi. Other reductions resulted from metabolic activities of different rotting organisms.

The effect of rotting on the chemical structure, and thus on the palatability of the fruit, is important to know. Also, it is expected that fermentation and acidification may occur in some or more cases of the attuits. The results thus showed that the percentage of sugars, protein, moisture were highly reded and the $\mathrm{pH}$ was significantly droped causing severe damage to the chemical constituents resulted in fermentation and acidification of the fruits.

This work showed that all fungi favour the growth in the designed medium of DPFA and DPLFA. DPLSA as a medium remained the least suitable medium and this may be because the majority of the fungi did not favour the growth in media with high concentrtion of sugars. Therefore, DPFA and DPLFA can be recommended as a useful media for the growth of these fungi.

Further studies are likely to reveal some of these points and to know more about the metabolic activities of the different pathogenic fungi on the chemical constituents of the date fruits.

\section{LITER ATURE CITED}

Abdulsalam, K.S. and Mussa, A.E. (1988). Preliminary evaluation of certain fungicides against fungi causing fruit rots of date palm (Phoenix dactylifera) in Saudi Arabia. Proc. of the Sec. Conf. of the Agr. Dev. Res., Fac. of Agr. Ain Shams Univ., Cairo, Egypt. 
AOAC (1970). Association of Official Agricultural Chemists. Of ficial Methods of Analysis (11th ed.), Washington, D.C.

Chohan, J.S. (1972). Diseases of date palm (Phoenix dactylifera L.) and their control. Punjab Hort. J., 12 (1), 25-32.

Djerbi, M. (1981). Diseases of the date palm. Tech. Bull. 2, FAO, Baghdad.

Elarosi, H. (1983). Studies on Plant Diseases Affecting Date Palm Tree at the Eastern Province of Saudi Arabia. Project No. AR 2-31 of King Abdulaziz City for Sci. and Tech. (KACST).

Elarosi, H., Mussa, A. E.A. and Jaheen, N. (1982). Date-Fruit rots in the Eastern Province of Saudi Arabia. Proc. of the Fr. Symp. on the Date Palm, Al-hassa, K.S.A., K.F.U. press.

Hussein, F. and El-Zeid, A. (1975). Chemical composition of Khalas dates grown in Saudi Arabia. Egypt. J. Hort. 2, 209-214.

Hussain, F., Mahdi, M. and El-zeid, A. (1975). Fruit growth and composition of some Saudi arabian soft date cultivars. Ann. Agric. Sci. (Moshtohor). 4, 193-202.

Hussein F., Moustafa, S. and El-Zeid, A. (1976). Preliminary investigation on compositional changes during fruit growth and ripening of Barhi and Sukari dates grown in Sudi Arabia. Egypt. J. Hort. 3, 45-53.

Pearson, D. (1973). Laboratory techniques in food analysis. 315 pp., Bullerworth.

Sawaya, W. N., Khalil, J.K., Safi, W.M. and Al-Shalhat, A. (1982). Physical and chemical characterization of three Saudi date cultivars at various stages of development. Canadian Inst. Fd. Sci. \& Tech. J. (In press).

Snedecor, G. and Cochran, W.G. (1974). Statistical Methods, 593 pp., lowa State Univ. Press, Ames, lowa. U.S.A.

Strong, F.M. and Koch, G.H. (1980). Biochemistry Laboratory Manual. 260 pp. Brown Co. Pub. 


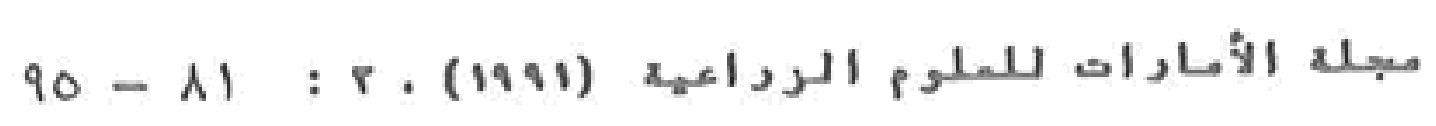

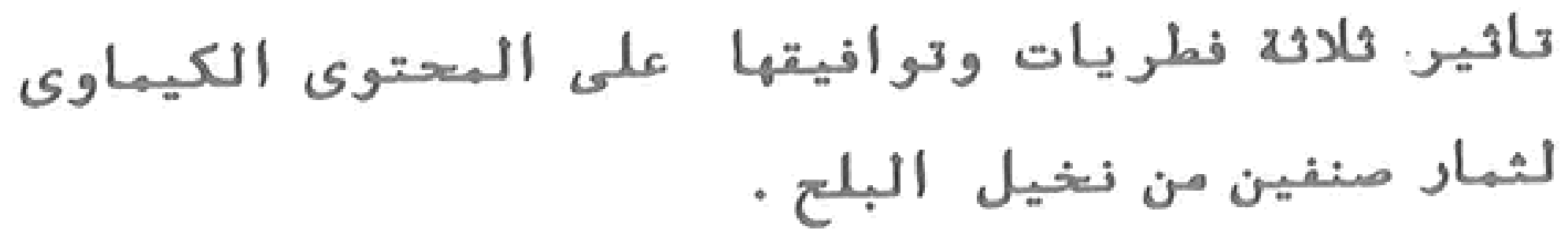

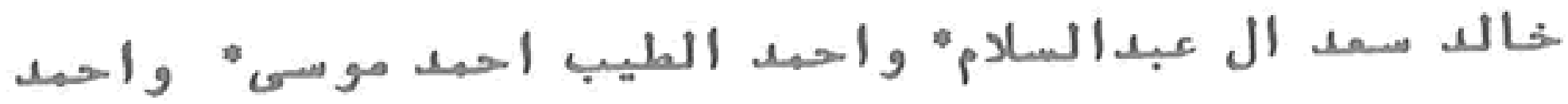

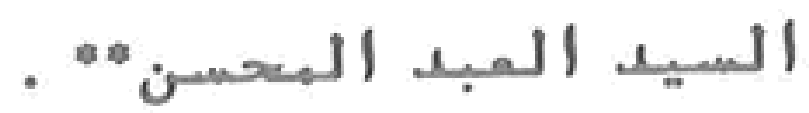

* كلية الزراعة ، جامعة الملك فيصل ، الهنوف ، الهملكة العربية السمودية.

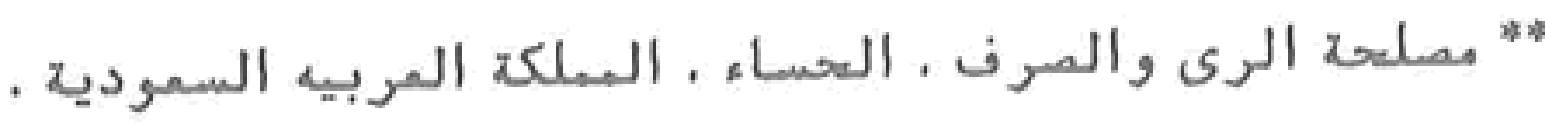

\section{2}

وجدت ثلاة نطريات ممرضح هى التركاريا التركانا واسبرجلس جابوبكس و ليجروسبورا وتوافيتها على ثلار البلع صنفى خصاب وشهل . وتد الضع ان هذه

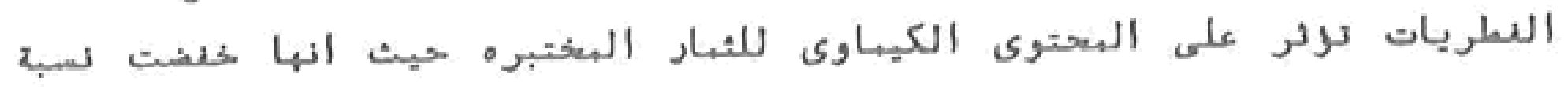
السكريات الكلية والسكريات الميختزل وغير المهتزله والبروتينات ودرجة الهموضة.

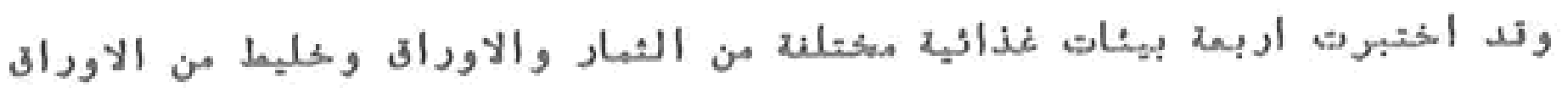

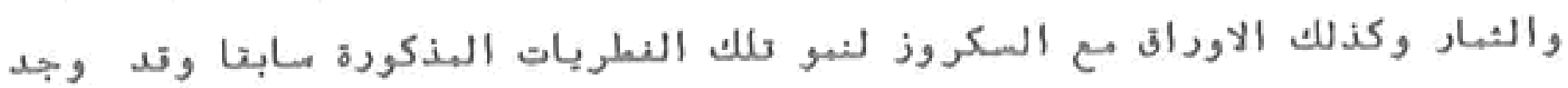
ان بيبة الاورات والثبار من انضل البيئات لتنميح هذه النطريات .

كلهات مفتاحية : دار البلع · السكروز ، نطريات . المتوى الكيماوى · 